\title{
Scripting the Revolution: Regicide in Russia
}

\section{Lisa Kirschenbaum}

On the night of 16-17 July 1918, agents of the Bolshevik political police, the Cheka, executed the former tsar and tsarina, their five children, the family doctor, and three servants in the basement of a house in Ekaterinburg. Shortly after the tsar's abdication in February 1917, the Provisional Government had held the imperial family under house arrest at the palace at Tsarskoe Selo. In July 1917, amid calls from the left to exact revolutionary justice, and fears that the right might try to restore the tsar, Alexander Kerensky, the moderate socialist head of the Provisional Government, decided to transfer the family to the isolated town of Tobol'sk in Siberia. The Bolshevik seizure of power in October 1917 initially had little impact on the lives of the exiled tsar and his family. In the spring of 1918, the Bolshevik-dominated Ural Regional Soviet arranged the transfer of the family from Tobol'sk to Ekaterinburg as a means of preempting rumoured monarchist plots to liberate the imperial family. In mid-July, the local Bolsheviks - whether on their own initiative or at the behest of Moscow remains an open question - summarily executed the imperial family as a means of keeping them out of the hands of the anti-Bolshevik forces threatening Ekaterinburg. The city fell to Czech forces shortly thereafter.

For the Bolsheviks, integrating the execution of Nicholas II into the narrative of the revolution proved problematic, in part because fixing the meaning of the tsar (but, somewhat paradoxically, not the tsarina) for an avowedly proletarian revolution was difficult, and in part because the murder itself played out in an untraditional and particularly unceremonious way. In October 1917, the Bolsheviks found themselves in the somewhat awkward situation of having staged a proletarian revolution in a country that had not yet executed its monarch. Trying Nicholas and carrying out the inevitable death sentence seemed both a necessary revolutionary phase and a powerful means of claiming the entire revolution - February and October - as a Bolshevik achievement. Yet the Bolshevik regicide hardly constituted an expected act of the proletarian revolution or an edifying re-enactment of the justice meted out by revolutionaries in England and France. As the local Ekaterinburg paper noted in its announcement of the tsar's execution, "the will of the revolution has been fulfilled, although in this case many of the formal features of bourgeois judicial process were violated, and the traditional-historical ritual (tseremonial) of the execution of monarchs was not observed."1

Subsequent Soviet accounts worked on one hand to excuse the departure from the expected revolutionary script, and on the other to demonstrate that a proletarian revolution had no use for the ceremony of bourgeois justice and its ritualized killing of kings. This dual approach complicated the effort to 


\section{Left History 7.2}

memorialize the regicide as a straightforward revolutionary break with the past or to enshrine it as a pivotal moment in the history of the Revolution. Narratives written in the decade after the execution of the imperial family struck an uneasy balance between the desire to endow the regicide with transcendent significance and the impulse to dismiss it as the "unheroic end of the most ordinary, everyday prisoner." In other words, there was no unequivocal answer to the question of whether the execution of Nicholas Romanov and his family was one of history's "great" revolutionary moments, or merely the routine shooting of a gang of bandits and speculators. Rather than providing a clear symbol of the demise of the old order, the destruction of the dynasty tended to raise vexing questions about the nature of the Bolshevik revolution and its enemies, the operation of revolutionary justice, and the role of individuals in the great revolutionary drama of the working class. By 1928, the regicide that had originally been represented as a necessary and momentous piece of the revolutionary drama largely disappeared from Soviet accounts of the Bolshevik revolution.

\section{REVOLUTIONARY SCENARIOS}

In Leon Trotsky's famous phrase, the Revolution of 1905 was the "dress rehearsal" for 1917. Vladimir Lenin had proposed much the same analogy as early as March 1917 in his "Letter from Afar" published in Pravda. Rejecting the then-current notion that the fall of the monarchy was some sort of "miracle," Lenin proposed a theatrical metaphor: the "eight day revolution was 'performed'... as though after a dozen major and minor rehearsals; the 'actors' knew each other, their parts, their places, and their setting in every detail." 3 More than a convenient way of emphasizing the links between 1905 and 1917, the metaphor proposed that revolutions, at least-after they occur, can be understood as coherent dramas.

The theatrical metaphor turned history into an anthology of well-rehearsed episodes and familiar characters that structured and dignified revolutionary improvisation. The "Great French Revolution" provided the most privileged and contested revolutionary script. ${ }^{4}$ The existence of such compelling historical templates did not mean that the current action was predictable. As Trotsky noted in his history of the Revolutions of 1917, no one guessed that the demonstrations on International Women's Day would lead to the abdication of the tsar. ${ }^{5}$ Borrowing from earlier revolutions, Russian revolutionaries engaged in the sort of scriptwriting that was common in contemporary cinema - they wrote and rewrote while the cameras rolled.

In revolutionary Russia, Marxists and non-Marxists alike tended to approach history in much the same way that seventeenth-century English radicals read the Bible: with "high expectations" and the conviction that all past revolutionary upheavals offered "a message of direct contemporary relevance." History functioned as a field guide to archetypal revolutionary set pieces that could be recognized, reworked, revitalized, and restaged in the revolutionary 
present. Working to situate themselves within the canon of progressive moments in history, the Bolsheviks represented themselves as the embattled republicans of 1793, the no-less-embattled Communards of 1871, and even as the great emancipator himself, Abraham Lincoln. ${ }^{7}$ As Vladimir Brovkin has noted in a different context, the Bolsheviks (and I would add non-Bolsheviks as well) felt acutely that their actions were "for the record." Making a "great" revolution meant making history on an epic scale.

The Bolsheviks were by no means alone in looking for and finding revolutionary parallels everywhere from seventeenth-century England to contemporary China. ${ }^{9}$ Such comparisons established the world historical significance of events in Russia. In a speech before the Petrograd Soviet in March 1917, Iurii Steklov, an inter-faction Social Democrat, traced the route of the French example of 1789 through Italy, Switzerland, Spain, England, Germany, back to Paris, and finally to Russia, where the fall of the worst of the tyrants promised to liberate the world. ${ }^{10}$ The revolution was understood as a "world" revolution both because it would remake the entire world and because it was part of an ongoing international historical drama. In newspaper accounts, events in Russia often became local and sometimes idiosyncratic productions of timeless revolutionary scenarios. The liberation of prisoners from the Shlüsselberg Fortress could be understood as Russia's storming of the Bastille. ${ }^{11}$ From the moment of the tsar's abdication, Nicholas II became the Russian Louis XVI and Alexandra the Russian Marie Antoinette. In the revolutionary imagination, the former tsar functioned as the talisman of counterrevolution, while his wife quickly became and long remained the embodiment of the immoral, foreign aristocracy indifferent to the plight of the people. ${ }^{12}$ In emphasizing the queen's illegitimate political power, her lasciviousness, and her treasonous ties with Germany, the brief against Alexandra clearly - if unwittingly - echoed the charges brought against the "Austrian whore" by the Jacobins. ${ }^{13}$ The tsarina's supposed liaison with Rasputin was the subject of much gossip and political pornography. In the wake of the February Revolution, the Bolsheviks allegedly sold "obscene pamphlets" featuring the tsarina and the peasant holy man. When soldiers desecrated Rasputin's tomb in March 1917, they covered the walls with "rude drawings of Rasputin scrubbing Alexandra in her bath." A year and a half later, White investigators found similar pornographic graffiti on the walls of the house in Ekaterinburg where the family was killed. ${ }^{14}$ Such images provided a powerful metaphor for a corrupt, anachronistic regime. As Michael Walzer has noted in his study of regicide and revolution, "The distribution of power for sexual reasons is the clearest possible expression of courtly decadence." 15

If Alexandra personified the decadence of the old regime, Nicholas seemed to embody its impotence and, paradoxically, the threat of counterrevolution. ${ }^{16}$ In early March 1917, the tone of the revolutionary press was euphoric, but also cautious; the magic that had transformed backward Russia into the freest 


\section{Left History 7.2}

country in the world might prove short lived. Accounts of the abdication expressed worry that "the hydra of reaction might yet rear its head." The former tsar often appeared in the press as "Nicholas the Bloody," a tyrant on a grand scale, the murderer of workers and revolutionaries, the "first landlord," a pogromshchik, and a warmonger. As such, he stood as a concrete menace to the revolution. His arrest, and, many popular voices added, punishment constituted matters of justice and necessity. ${ }^{17}$ On the other hand Nicholas himself could be understood as unimportant, pathetic, the sorry product of a dying system, the puppet of capitalists and scheming ministers. ${ }^{18}$ Yet even as the pawn of forces larger than himself, Nicholas posed a substantial, if symbolic, threat. He might, as Trotsky expressed it much later, provide "a live banner [for the Whites] to rally around."19

The French script both fueled and substantiated fears of monarchist plots. Facing increasingly radical opposition in the summer of 1917, moderate socialists cast themselves as the defenders of the infant Republic bravely battling counterrevolutionary conspiracy. ${ }^{20}$ Any attack on their idea of revolution became an attack on revolution per se. Thus in June 1917, Izvestiia, the official voice of the Menshevik-dominated Petrograd Soviet, equated Bolshevik calls for the ouster of capitalist ministers with the anti-Semitic propaganda of the Black Hundreds. A month later, revolutionaries uncomfortable with the Bolsheviks' increasingly aggressive rhetoric and actions labeled them, somewhat incongruously, as Jacobins, Bonapartists, German agents, and monarchists. ${ }^{21}$

In the months between the fall of the dynasty and the Bolshevik seizure of power, socialists paid a great deal of attention to the questions of where Russia stood in the arc of revolutionary action suggested by the French Revolution and of who was playing which role. Thus at the Congress of Soviets in June 1917, delegates from across the political spectrum accepted debate on the meaning of "the year 1792" in France as immediately relevant to the present and future of revolution in Russia. Lenin, whose Bolsheviks were in the minority, urged the soviets to follow the example of republican France, and pursue revolution rather than reform. Explicitly forswearing the guillotine, he advocated the arrest of 50 or 100 millionaires for a week or so. Lenin pictured the Bolsheviks as twentiethcentury Jacobins. ${ }^{22}$ Kerensky, who clearly preferred the Rights of Man and Citizen to the Republic of Virtue, offered a different vision of events in France. Arguing that the Jacobins of 1792 succeeded only in producing dictatorship, Kerensky counseled caution. But neither he nor anyone else denied the pertinence of the French script. ${ }^{23}$

The sense of participating in and remaking a long and venerable revolutionary tradition shaped the responses of revolutionaries across the political spectrum to the prospect of regicide. Kerensky explained his unwillingness to preside over the execution of Nicholas II as a refusal "to be the Marat of the Russian Revolution."24 Other moderates in the Provisional 
Government, who viewed the execution of Louis XVI as the first act of revolutionary terror, worked to discourage expectations that Nicholas II would necessarily meet a violent end. As calls for "revenge" against the imprisoned tsar became more frequent, moderates emphasized that mob justice had no place in a civilized revolution. ${ }^{25}$ The July 1917 transfer of the imperial family from house arrest in Tsarskoe Selo to Tobol'sk had obvious symbolism, but an item explaining the move in Izvestiia emphasized that the point was to ensure the tsar's safety and to keep him out of the hands of counter-revolutionaries. In this case, Siberian exile was in no way punitive. ${ }^{26}$ By contrast, the Bolsheviks, even before they seized power in October 1917, presented themselves as ready to play the role of Jacobins, presumably with Lenin as Marat, ${ }^{27}$ although regicide hardly constituted an expected or prominent item on the agenda of the workers' revolution.

While the Jacobins could inspire both admiration and revulsion, Napoleon represented the outcome everyone agreed needed to be avoided. Precisely who was preparing to play the role remained an open question, and the image of Napoleon proved powerful and malleable. After the July 1917 demonstrations in support of "All Power to the Soviets," moderate socialists came to see the Bolsheviks as a party of Napoleons ready to destroy revolutionary freedom. After October, the Bolsheviks' opponents continued to attack them as "Bonapartists," a charge communists answered with the axiom that a workers' party could never play the role of Napoleon. The Bolsheviks for their part cast Kerensky or General Lavr Kornilov, who attempted a military coup in August 1917 (or a long list of other military leaders throughout the Civil War) as Napoleon. As early as May 1917, Lenin leveled charges of "Bonapartism" at Kerensky. By September, the Bolshevik press pictured revolution as a struggle between the proletariat and an increasingly desperate bourgeoisie ready to rely on a Napoleon. ${ }^{28}$

This sort of "labeling" of political enemies has been understood as a particularly insidious and disingenuous feature of Bolshevism. ${ }^{29}$ But the frequency with which leaders as diverse as Kerensky and Lenin reached for such pejoratives suggests a shared, if contested, vocabulary. More than a way to smear the opposition, invoking the characters and scenarios of the revolutionary past provided a fundamental means of explaining and legitimizing revolutionary action and of claiming a place in revolutionary history.

\section{BOLSHEVIKS AS JACOBINS}

In October 1917, the Bolsheviks took power from the Provisional Government that had been formed in February. They represented their actions as a proletarian revolution, a clear rejection of the bourgeois settlement of February. Still, the Bolsheviks continued to draw on analogies to other "great," if bourgeois, revolutions as a means of exalting their actions and of imagining revolutionary futures. An anti-Bolshevik uprising in the Don basin became a 
"Russian Vendée," and was thereby doomed to failure. ${ }^{30}$ A week after the Bolsheviks took power, an article in Pravda noted that "we are literally reading our own history" in accounts of the revolution of 1848 and the Paris Commune, adding that in Russia, where the revolution had the support of the peasants, the outcome would "obviously" be far happier. ${ }^{31}$ The October Revolution might have established the "world's first socialist democracy," but because it followed "historical laws," the action was familiar. ${ }^{32}$ In the summer of 1918, at a time when the Bolsheviks faced mounting threats to their revolution - one historian has described the Soviet leadership in July as in a state of "panic" - they took courage from the revolutionary elan of the army of the French republic. ${ }^{33}$

The Bolsheviks had long welcomed the Jacobin designation, and by early 1918, they were demonstrating an increasing ease with the violence widely associated with the label. From Lenin's statement in the summer of 1917 that the guillotine would not be necessary, the Bolsheviks in power moved toward the stance that in a republic under siege radical action might be both unavoidable and salutary. ${ }^{34}$ Less than two weeks after the October Revolution, Izvestiia quoted with approval Heinrich Heine's Saint-Just: "The Committee of Public Safety was told/ By Saint-Just once to their noses:/ You can't cure grave ills of society/ With musk and attar of roses."35

In the greatest of revolutionary dramas, the killing of the king constituted a pivotal moment, ${ }^{36}$ and the Bolsheviks continued to understand regicide in terms of the French example, despite the fact that Nicholas II was a rather unrepresentative example of the class enemies of the proletariat. The Bolsheviks seemed to assume that the public trial and execution of Nicholas II - something that a truly competent bourgeois revolution would have already accomplishedwould simply update the French script. Looking back in 1935, Trotsky remembered proposing "an open court trial... broadcast throughout the country by radio." 37 A political cartoon appearing in Pravda in late 1917 placed the image of Louis XVI holding his own head in front of a crowd of familiar Russian reactionaries: clerics, officers, well-fed capitalists (fig. 1). "Nicholas the Bloody" became "Louis XVII"; the caption warned that "counterrevolutionaries complain about bloodshed, but they're walking around with their heads on their shoulders." 38 By evoking 1793, the image managed at once to emphasize Bolshevik restraint and to leave little doubt as to the justice of revolutionary violence.

Nowhere were the tensions between the desire to claim the epic mantle of the French Revolution and the effort to follow a new, self-consciously proletarian script clearer than in Bolshevik representations of Nicholas II. From the Marxist point of view, the former tsar was largely an irrelevancy. Lenin often dismissed him as the "idiot Romanov," a somewhat embarrassing vestige of a "semi-feudal" Russia of sleigh bells and peasant holy men. ${ }^{39}$ It was wrong, Lenin asserted in August 1918, "to blame kings and tsars" for the world war; "it was brought about by capital." Unlike their SR opponents, the Bolsheviks did 


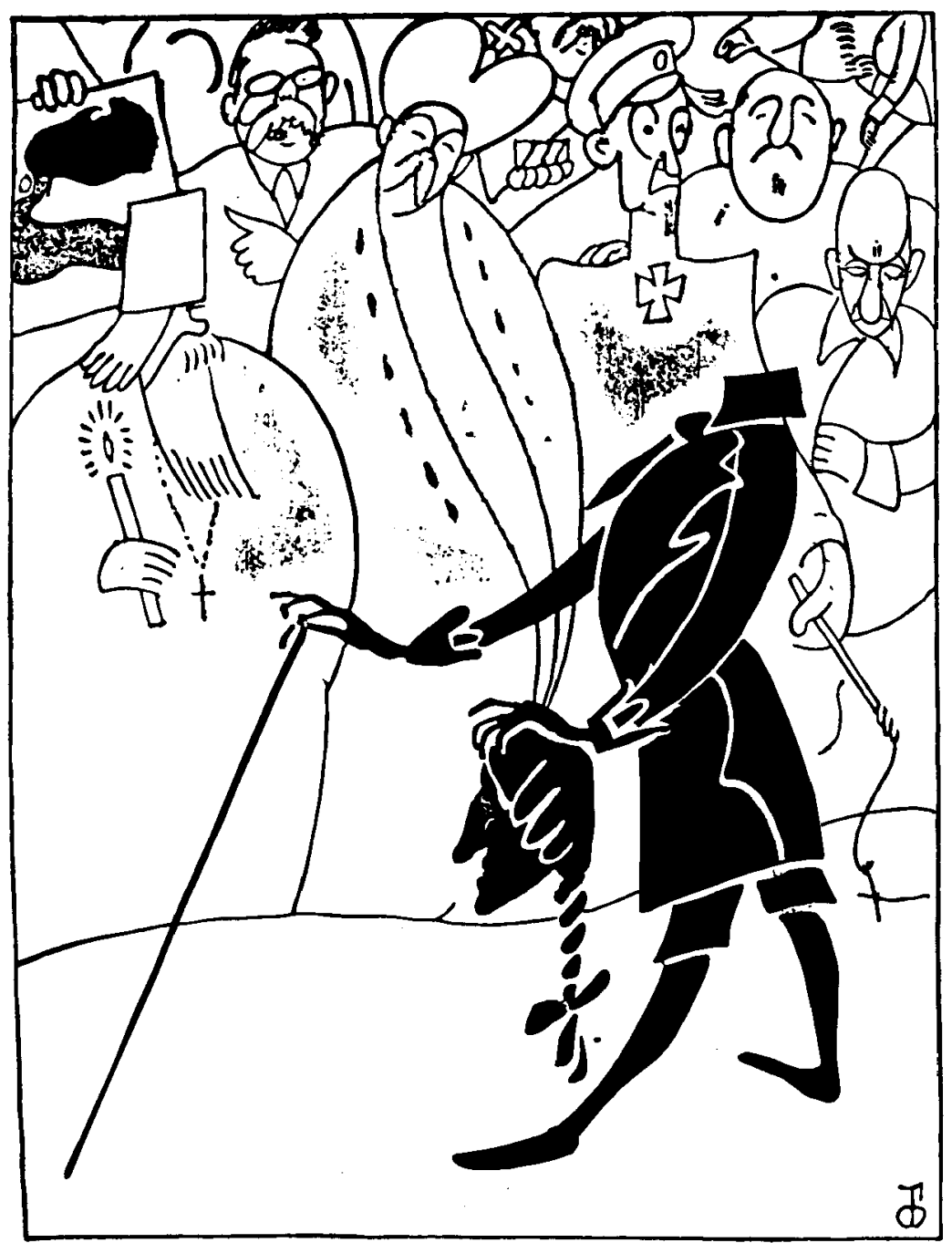

Л АОВиКТ XVII: Удивительнал страна Россія! Каяуютсл они на кровопролитlе- а контръ-революцाонеры ХоАлть со своими головами на плечахв.

Figure 1: "Louis XVII: Astonishing Russia! Counter-revolutionaries complain of bloodshed, but they're walking around with their heads on their shoulders." Pravda, 19 Dec. 1917. 
36 Left History 7.2

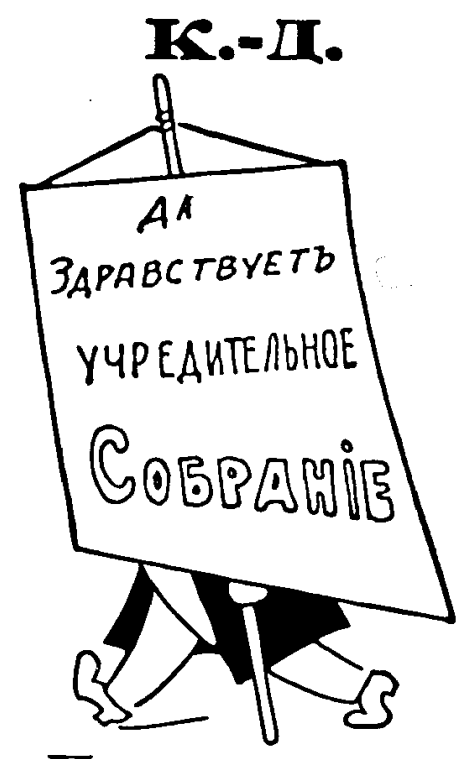

Подт маско i.

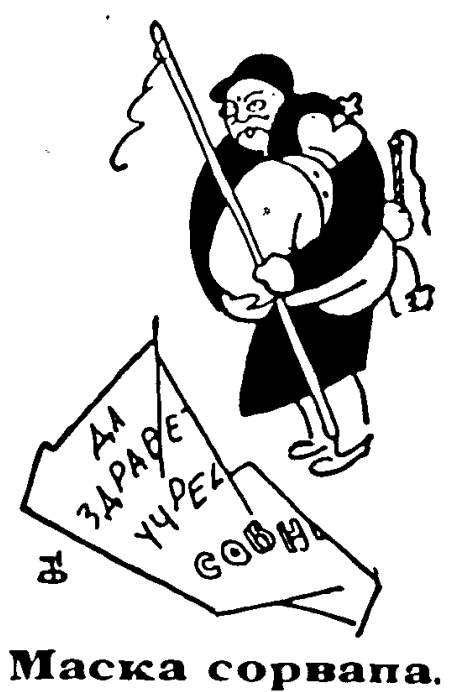

Figure 2: The Kadet Party "Masked" and "Unmasked." The banner reads, "Long Live the Constituent Assembly." Pravda, 13 Dec. 1917. In January 1918, the Constituent Assembly met for the first time, and was quickly prorogued by the Bolsheviks. 


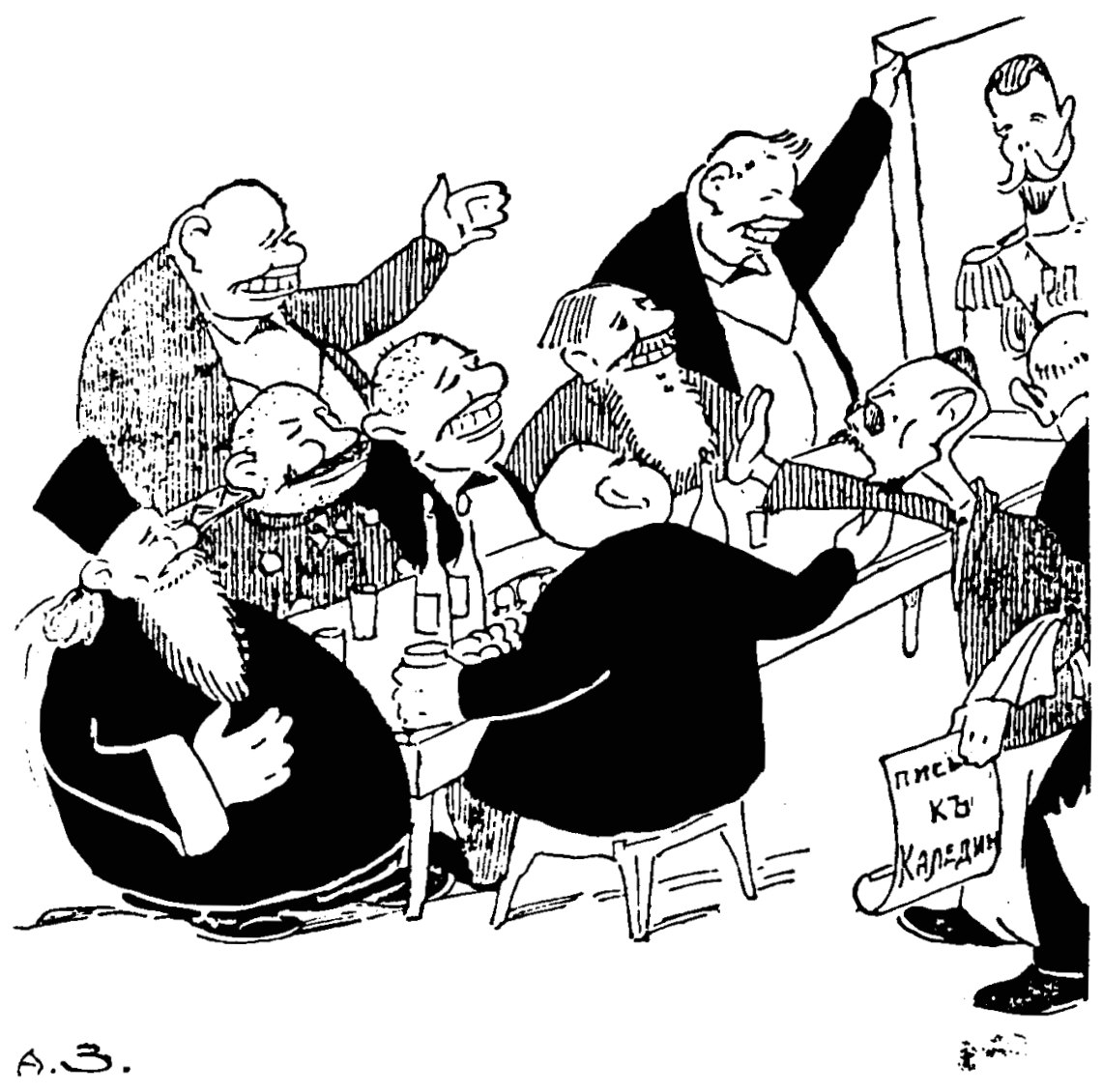

TAVHAR BEYEPA.

Figure 3: "The Last Supper," Pravda, 8 Nov. 1917. 


\section{Left History 7.2}

not believe that a few well-coordinated assassinations would change the world $^{40}$ Yet such Marxist commonsense did not diminish the tsar's counterrevolutionary power. The telescoping of revolutionary "phases" in Russia allowed the tsar, or, more accurately, the notion of a "former tsar," to remain, for the Bolsheviks along with other revolutionaries, a potent symbol of the almost miraculous transformation wrought by revolution. ${ }^{41}$

In Bolshevik representations of the tsar, there was a clear tension between the need to catalog the legendary horrors of "Louis XVII" and the impulse to turn citizen Romanov into a prosaic, recognizable representative of the bourgeoisie. Nicholas the Bloody, who fit well into the French script, shared the stage with Nicholas the "bloodsucker," the "first capitalist," and the narrowminded, uncultured speculator, who better fit the Bolshevik notion of class enemy. The kaleidoscopic, multivalent embodiment of constantly shifting antiBolshevik "conspiracies," Nicholas could be found everywhere, in a multitude of guises, the heart of the "hydra of counterrevolution." Actually, the Bolsheviks's opponents, recognizing the depth of popular feeling against the tsar, rarely evoked him; indeed, few favored restoring the dynasty. ${ }^{42}$ However, in the Bolshevik imagination, Nicholas's passive image seemed to possess an unholy power to unite the motley "apostles" of counterrevolution. At a "last supper" pictured in Pravda, capitalists, officers, and priests flashed toothy grins at a portrait of Nicholas II. (fig. 3 ). ${ }^{43}$

The former tsar could function as the symbol of every possible shade of counterrevolution largely because, as imagined by the Bolsheviks, he lacked a fixed class location. Nicholas was represented as king, capitalist, and pettybourgeois shopkeeper. From the first, descriptions of the former imperial family represented Alexandra as possessing the qualities (all negative, to be sure) of a true aristocrat, while emphasizing the tsar's drunkenness, "limited mental capacity," and narrowminded pettiness. ${ }^{44}$

From the Marxist point of view, conspiracy theories made a certain sort of sense. If tsarism ultimately served the class interests of the bourgeoisie, then contrary to expectation (and to the experience of February) the bourgeoisie, along with the Mensheviks and "white SR's," must be monarchist at heart. As Lenin explained it, "the dirty work of the Russian capitalists and landowners, who were in fact continuing the policy of the tsar the people had overthrown, was covered up by the Mensheviks and Socialist Revolutionaries, who pretended to be socialists while actually betraying socialism in the interests of the British and French stock exchanges." 45 Soviet newspapers published a constant stream of revelations about far-reaching monarchist conspiracies involving improbable combinations of Black Hundreds, Kadets, foreign diplomats, Socialist Revolutionaries (SR's), White generals, Mensheviks, and bankers. ${ }^{46}$

Locating the king at the center of counterrevolutionary plots also made sense in terms of the French script. Conspiracies had constituted a central feature of the symbolic universe of the French Revolution. François Furet 
explains the "aristocratic plot" as "the lever of an egalitarian ideology that was both exclusionary and highly integrative... the nation was constituted by the patriots only in reaction to its adversaries, who were secretly manipulated by the aristocrats. ${ }^{\circ 7}$ The plot served a similar function in Russia.

Anticipating "great events," but shaken by military setbacks and, at the end of August, the attempted murder of Lenin, the Bolsheviks found monarchist conspiracy everywhere. ${ }^{48}$ The diversity of their enemies meant that the Bolsheviks' notion of "restoration" had to be quite capacious, containing at once the desires of reactionary monarchists, the liberal bourgeoisie, and the "imperialists" intervening in the civil war. (They dismissed moderate socialists as the "lackeys" of the bourgeoisie) ${ }^{49}$ Their opponents, whatever their politics or class origin, became "objectively" monarchist. The Bolsheviks insisted that there could be only "two camps," and eventually not only the liberal Kadets but also Mensheviks and left SR's ended up on the "monarchist" side of the barricades. ${ }^{50}$ The Bolshevik press insisted that anyone - even those who had suffered exile and prison in the fight against tsarism - who opposed the Bolsheviks, "i.e., the workers and peasants," was as much a counterrevolutionary as the most rabid monarchist. ${ }^{51}$ This Manichaean language allowed the Bolsheviks to define their own actions as transparent, and to "unmask" all those who hid a desire to restore the pre-February status quo under the "pseudonym" of liberalism or even Marxism (see fig. 2) ${ }^{52}$ From this point of view, the decision to prorogue the Constituent Assembly in January 1918 could be represented as an effort to "save" the revolution from a body in which Bolsheviks were in the minority. Shutting down the assembly that they themselves had clamored for before October, the Bolsheviks represented themselves as the only actors who were not dissimulators.

Turning Nicholas himself into the eye of the counterrevolutionary storm emphasized the Bolshevik claim that their revolution was the (true) revolution. Especially as erstwhile allies became enemies, it became essential for the Bolsheviks to cast themselves as the only legitimate revolutionaries. In Soviet accounts, even the often politically dim Nicholas recognized that in the Bolsheviks he met "real revolutionaries" for the first time. ${ }^{53}$ The presence of the former tsar on the anti-Bolshevik side of the barricades ruled out the possibility of a loyal opposition, and made regicide a legitimate phase of proletarian revolution.

Still, staging the regicide remained a low priority. In the chaotic civil war conditions of 1918, organizing a trial in Moscow was no simple matter. The Bolshevik leaders in the Kremlin had more pressing concerns, and local Bolsheviks had other ideas. Trotsky later remembered bringing the matter up at Politburo meeting "a few weeks before the execution of the Romanovs." He suggested that "considering the bad situation in the Urals, it would be expedient to accelerate the Tsar's trial." Lenin opined that a trial "would be very good if it were feasible," and Trotsky let the matter drop. ${ }^{54}$ Historian Richard Pipes has 
argued that the leadership in Moscow sent Vasilii lakovlev, a "tried and trusted Bolshevik," to Tobol'sk in April 1918 with the task of bringing Nicholas, if not the rest of his family, back to the capital. However, "hotheads" from Ekaterinburg, who were committed to the summary execution of the tsar, thwarted the proposed transfer to Moscow, and moved the tsar and his family to Ekaterinburg instead. According to Pipes, the leadership in Moscow did not object to the change in plans. ${ }^{55}$

As is well known, the Bolsheviks never publicly tried Nicholas II. Precisely what happened to the imperial family, and at whose order has become one of the revolution's minor mysteries. Soviet newspapers initially reported that Nicholas II had been shot, his wife and son evacuated to a secure location. In other words, initial accounts grossly misstated or at best understated what had actually happened - or rather what White investigators and later Soviet sources claimed happened. The regime admitted the murder of the rest of the family only in $1921 .^{56}$ All sorts of reasons for failing to report the murders of the entire imperial family have been proposed: uncertain information from the local Soviet that carried out the murders; a desire to cover up what had never been sanctioned by Moscow; fears of popular outrage at the killing of innocent women and children; an effort to placate Socialist Revolutionaries, who were clamoring for revolutionary justice while the Bolsheviks continued to negotiate the family's safe passage to Germany. ${ }^{57}$

However compelling, such pragmatic explanations tend to devalue the symbolic dimensions of the killing of the king. Newspaper accounts explained the regicide as a straightforward response to fears that the advancing Czechs would liberate the tsar. But at least for the leadership in Moscow, regicide was more than a means to an end; it was an integral part of the drama of history's "great" revolutions. Whatever practical difficulties it solved or posed, the hasty shooting of the last of the Romanovs in a basement in Ekaterinburg did not make for inspiring or traditional revolutionary theater. Symbolic considerations help explain why newspapers provided no details of the regicide, aside from the fact that Nicholas had been shot - the modern revolution's preferred method of execution. As Trotsky noted much later, "Under judicial procedures, of course, execution of the family would have been impossible." 58 Such seemingly legalistic considerations mattered to those who hoped to emphasize the historic parallels between events in Russia and earlier "great" revolutions. Trotsky recognized that "[i]n the intellectual circles of the Party" the murder of the imperial family "probably" produced "misgivings and shakings of heads." Indeed Trotsky remembered his own seemingly involuntary surprise when on his visit to Moscow after the fall of Ekaterinburg, he asked Lenin's assistant Iakov Sverdlov "in passing: 'Oh yes, and where is the Tsar?"

"It's all over," he answered, "he has been shot." "And where is the family?" "And the family along with him." "All of them?" I asked, 
apparently with a touch of surprise. "All of them!" replied Sverdlov, "What about it?" He was waiting to see my reaction. I made no reply. 59

Instead of emphasizing the proletarian toughness of Sverdlov's "What about it?", Soviet newspapers presented a post factum trial of the former tsar, and emphasized the regicide's powerful historical antecedents. Articles and editorials overflowed with details of Nicholas's crimes that served to situate him in the elite, if less-than-enviable, company of Charles I and Louis XVI. ${ }^{60}$ Since initial press accounts failed to mention the tsarina's execution, parallels with Marie-Antoinette were never made explicit in the Bolshevik press. ${ }^{61}$ Historical comparisons that purportedly revealed Nicholas's unprecedented criminality excused the failure to stage a public trial. Additionally, Pravda reminded its readers that Robespierre had advocated a summary military-style execution of Louis XVI. ${ }^{62}$ The Bolsheviks initially attempted to endow their problematic regicide with revolutionary weight and drama by casting Nicholas II as the descendant of Charles I and Louis XVI, and themselves as the unsentimental heirs of the Jacobins.

\section{JUSTICE, RITUAL, AND COMMEMORATION}

After Nicholas's death, the conviction that monarchist vipers were everywhere remained very much alive ${ }^{63}$ Recognizing that nothing captured the sense of "before" and "after" better than the former tsar, the Bolsheviks continued to represent themselves as both the champions of the working class and the only defenders of the gains of February. A history of the revolution published in 1918 argued that "Had there been no October, Nicholas or Michael would already be reinstalled in the Winter Palace."64 27 February, 1918, the anniversary of the fall of the monarchy, became the "anniversary of the socialist revolution." ${ }^{\circ 5}$ The following year, the convocation of the Third International overshadowed the commemoration of the end of the old order. Labeling the opposition "monarchist" was more than conveniently insulting; it allowed the Bolsheviks to link February to October and to represent both as Bolshevik triumphs.

The failure to stage a public trial constituted the most immediate obstacle to commemorating the killing of Nicholas II as the Russian version of the regicides in England and France. Indeed for the regime's critics, the failure is the mark of the revolution's illegitimacy. ${ }^{66}$ As noted above, the Bolsheviks initially excused the failure to stage a trial as the only way to keep Nicholas from falling into the hands of the Whites and as the sort of justice Jacobins would have applauded. Later accounts ignored the historical parallels, instead pleading only extenuating circumstances. All emphasized that a trial had been in the works. However, the extremely precarious position of Ekaterinburg (which fell to the Whites shortly after the murders) prompted the local authorities to carry out the 
inevitable death sentence without the formalities ${ }^{67}$ The litany of the regime's crimes served to underline the correctness of the sentence.

Alongside the insistence that a trial was the ultimate goal, Soviet accounts of the regicide also expressed doubts that such a trial was necessary or appropriate in the context of a workers' revolution. For Trotsky, the execution of the entire family "was needed not only in order to frighten, horrify, and dishearten the enemy, but also in order to shake up our own ranks." Only summary justice could produce such a decisive result. Bourgeois legal convention, Trotsky noted, would not have sanctioned the imposition of the death sentence on the family. (He did not mention the precedent for killing the queen) ${ }^{68}$ Other accounts more bluntly asserted that the tsar and his family simply received the same sort of justice all class enemies received in those years. ${ }^{69}$

The "histories" of the imperial family's imprisonment and execution that appeared in the 1920s stressed the purportedly class-specific personal characteristics of the Romanovs as much as the class basis of the old regime. Written by eyewitnesses, often in the first person, these accounts picked up and expanded the image of the spineless, "dead drunk" tsar dominated by the "hysterical," "German" tsarina. ${ }^{70}$ In one telling incident, Aleksandr Avdeev, the commandant of the house in Ekaterinburg to which the family was transferred in the spring of 1918, recounted the former imperial couple's very different reactions to the reduction in their personal staff. While the imperious Alexandra protested loudly in English, Nicholas, seemingly more at home with the conventions of the marketplace than the palace, calmly haggled (torgovalsia) with the Bolsheviks. Avdeev saw the tsar not as "Nicholas the Bloody," the terrible and awesome former head of state, but instead as an uncouth, petty bourgeois butcher (miasnik not palach).$^{71}$ Such an enemy hardly required the ritual of a public trial broadcast across the nation on radio.

The method of execution also established the Russian regicide as authentically proletarian. Soviet narratives of the regicide, in contrast to the White accounts that they sometimes took as their foil, omitted the ugly details of the murder scene. What they foregrounded instead was the revolver as the "extremely democratizing" tool of proletarian justice. Whereas anti-Soviet accounts named names and often provided pictures of the murderers, in the Soviet telling "Nagant revolver shots finished off the condemned."72 The actual shooting seems not to have come off quite so clinically. ${ }^{73}$ But it was represented as swift, no-nonsense justice.

Indeed efficiency and planning emerged as key features of Soviet-style justice. The Bolshevik officials who presided over the imprisonment and execution of the imperial family pictured themselves as resisting the demands of Socialist Revolutionaries, anarchists, and overzealous workers for the immediate execution without trial (rasprava) of the tsar. ${ }^{74}$ The Bolshevik tone of superiority is somewhat surprising, given that the entire family was eventually executed without trial. The crucial difference was not the outcome, but the 
process - revolutionary discipline versus revolutionary recklessness. Bolshevik justice could violate the legal niceties, but it always respected administrative procedure and the will of the party. ${ }^{75}$

In Bolshevik histories written in the twenties, the regicide was first and foremost a successful government and party operation. Effective administration stood in for "bourgeois" notions of legality. The centerpiece of these accounts was often the transfer of the tsar, tsarina, and one of the grand duchesses from Tobol'sk to Ekaterinburg in late April 1918. This hazardous and important operation was described in far more detail than the shooting itself. The Ekaterinburg Bolsheviks represented themselves as overcoming the natural obstacles to travel in the early spring as well as the apparent double cross of the commissar sent from Moscow as they removed the tsar from a city honeycombed with counter-revolutionaries to the capital of the "Red Urals." Like Kerensky, who touted the secret transfer of the family from Tsarskoe Selo to Tobol'sk as "a striking illustration of the smooth operation of the administrative machine by the summer of 1917," the Bolsheviks viewed the passage to Ekaterinburg (along with the regicide and the effective disposal of the bodies) as a triumph of organization. ${ }^{76}$

The accounts of the regicide that appeared in the twenties combined personal recollections with impersonal narratives of the revolutionary situation in the Urals and the technical aspects of the former imperial family's imprisonment and execution. The regicide existed at the intersection of smallscale human drama and the epic theater of revolution. In the final act in Ekaterinburg, abstractions faced one another: "the bullets of red guard revolvers cut short the life of the crowned bandit," and the new world unsentimentally destroyed the old. ${ }^{77}$ Elsewhere, the details of the imperial family's life in captivity humanized both the prisoners and their captors. This seems to be especially true with regard to the children. In a bid to soften up the Reds, Grand Duchess Maria flirted with the guards. Finding Alexei singing "To the fallen," the commandant provided the heir with a revolutionary songbook, which the tsarina promptly consigned to the fire ${ }^{78}$ Tempered as they were with the everyday, the Bolshevik narratives resisted monumentalization.

Initially, the Bolsheviks had represented the killing of the king (the only murder they reported) as a critical practical and symbolic moment in the revolutionary drama, an event whose importance was preordained by the "Great" English and French Revolutions. In the heady and dangerous days of the Civil War, the Russian version's lack of the double ritual of public trial and execution seemed to mark it as authentically proletarian - ruthlessly efficient and aggressively unromantic. Writing in the fading spirit of the Civil War, Pavel Bykov, who had chaired the Ekaterinburg Soviet, opened his 1921 account of the "last days of the last tsar" with the declaration that "the Ural workers are proud not only of their active participation in the proletarian revolution, but also of the fact that in the deepest bowels of the Ural mountains lie the worthless remains of 


\section{Left History 7.2}

a tyrant, who paid with his life" for centuries of oppression. Bykov characterized the decisions of the soviets in Ekaterinburg, Perm, and Alapaevsk to "destroy everyone close to the autocratic throne" as "bold and decisive." He recounted the story not in order to justify the murders, but because it was good to tell of the deaths of kings. Publicizing the recollections of comrades involved in these events served "to drive the aspen stake deeper into the grave of the Russian autocracy."79

The expanded version of Bykov's account, published in the quieter days of the mid-twenties, took a noticeably more defensive tone. The workers unabashedly proud of their role in the regicide are nowhere in sight. Recalling an ethos and a style no longer in ascendance, the regicide itself became almost a footnote. The longer account included even fewer details of the murders than had the 1921 article. The executioners remained the anonymous agents of class justice. However, Bykov seemed to recognize that White efforts to uncover the specifics of the execution itself threatened to turn justice into murder. His last chapter lampooned the White investigators who, following up even the most absurd rumors, set about digging up the garden of the house in which the family had been killed in hopes of discovering the body of Nicholas II. He also made an explicit effort to balance the Red regicide against White terror. Many Bolsheviks (and some SR's), he noted, paid with their lives to ensure the death of the dynasty. In this version, the defeat of Admiral Kolchak, rather than the memorializing of the regicide, "drove the aspen stake deeper into the grave of the Romanov dynasty." 80

In both of Bykov's accounts and in those produced to mark the tenth anniversary of the destruction of the dynasty, the regicide was shorn of its histrionics and lost its status as a key moment in the master narrative of revolution. Both the failure and the rejection of the effort to legitimize and explain the Bolshevik revolution by linking it to an international revolutionary tradition worked to turn the regicide into a "non-event." When it became clear by 1921 that the Russian revolution would not become an irresistible example for the rest of the world, universalizing historical analogies became reminders of failed expectations. Always a problematic episode of proletarian revolution, the killing of the king was replaced by symbols and narratives generated by the process of revolution in Russia. The rhetoric of conspiracies and "two camps" as well as the practice of substituting efficient administration for "bourgeois" legality remained very much in evidence. But by 1930 , the revolutionary front had shifted. The "restoration" of the monarchy was no longer the galvanizing image that it had been during the Civil War. Trotsky replaced Nicholas as the constantly reinvented pivot of counterrevolution. Moreover, revolution was no longer conceived as an international drama; world revolution had given way to "socialism in one country." The critics of the Stalinist "revolution," first among them Trotsky warning of a Russian Thermidor, became the sole purveyors of analogies with France. ${ }^{81}$ 
Paradoxically, and somewhat reluctantly, commemorations of the regicide concluded that it deserved no special attention. In the accounts of the late twenties, commemorating competed not so much with forgetting as nonchalance. ${ }^{82}$ The calm disinterest of the Council of People's Commissars upon hearing the news of the regicide became a model of the appropriate response to the end of the dynasty. ${ }^{83}$ Bykov reported that the regicide was little noticed at the time and little commented upon later because people were absorbed in "gigantic creative work and great revolutionary struggle." 84 In the 1930 edition of his work, he ended with the tangible product of the struggle: the Mashinostroi works rising up near the spot where the "bones of the last tsar rotted in a swamp." This new monument eclipsed the only commemoration of the regicide in Ekaterinburg, the "Square of the People's Vengeance." 85 As V. Vorob'ev, the editor of the Ural Worker, noted, "this sort of thing doesn't happen every day, the execution of a tsar!" He himself participated in the most dramatic moment of his narrative, waiting nervously with members of the local soviet for word by telegraph that their extraordinary act had Moscow's approval. Vorob'ev's sense of the momentousness of the occasion stands in contrast to his conclusion that the "entire revolutionary nation" met the news in the same (implicitly correct) way that Lenin and the other commissars had - by quietly getting on with their business. The extraordinary officially became routine. ${ }^{86}$ The regicide became important again only on the eve of the Soviet Union's collapse, when it functioned as a key scene in a very different historical drama. ${ }^{87}$

${ }^{1}$.Quoted in G. Z. Ioffe, Krakh Rossiiskoi monarkhicheskoi kontrrevoliutsii (Moscow 1977), 166.

2. V. Vorob'ev, "Konets Romanovykh (K desiatiletiiu kazni Nikolaia II). Iz vospomininanii," Prozhektor No. 29 (15 July 1928), 26.

3.Leon Trotsky, My Life (London 1930), 161. On Trotsky's use of "the image of history as theater," see Peter Beilharz, "Trotsky as Historian," History Workshop Journal 20 (Autumn 1985): 41-43; Lenin, "Pervyi etap pervoi revoliutsii (Pis'ma izdaleka; pismo 1-e), Pravda, 21 March 1917.

${ }^{4}$.On the meanings and use of the French Revolution in Russia see John Keep, "1917: The Tyranny of Paris Over Petrograd," Soviet Studies 20 (July 1968): 2235; Dmitry Shlapentokh, The French Revolution and the Russian AntiDemocratic Tradition: A Case of False Consciousness (New Brunswick, N.J. 1997). Victoria Bonnell examines the Bolsheviks' use of French revolutionary symbols in "The Representation of Women in Early Soviet Political Art," The Russian Review 50 (1991): 270-273.

${ }^{5}$ Leon Trotsky, The History of the Russian Revolution: Three Volumes in One, trans. Max Eastman (New York 1936), I: 101-102.

${ }^{6}$.Christopher Hill, The World Turned Upside Down: Radical Ideas During the English Revolution (London 1975), 93.

${ }^{7}$ For the Lincoln parallel see "Belyi terror," Izvestiia, 1 Dec. 1917 
8.Vladimir Brovkin, Behind the Front Lines of the Civil War: Political Parties and Social Movements in Russia, 1918-1922 (Princeton 1994), 13.

9 ."Poidem-li my za kitaem?" Izvestiia, 5 March 1917.

10. "Zasedanie Soveta Rabochikh i Soldatskikh Deputatov 14-go marta (iz stenogrammy)," Izvestiia, 18 March 1917. See also Kamenev's speech at the same session. "Velikoe znachenie momenta," Izvestiia, 2 Nov. 1917; "Eshche o kadetakh," Pravda, 26 Nov. 1917; "Mirovoe znachenie russkoi revoliutsii," Pravda, 24 Dec. 1917; "Rech' Martova," Izvestiia, 7 June 1917.

11 "Vziatie Shlissel'burga," Izvestiia, 2 March 1917. A broader use of July 14 can be found in "14-e iiulia," Pravda, 14 July 1918.

12. "K perevodu byvshago tsaria iz Tobol'ska v Ekaterinburg," Izvestiia, 16 May 1918; P. M. Bykov, "Poslednie dni poslednego tsaria" in Rabochaia revoliutsiia na Urale: Epizody i fakty, ed. N. I. Nikolaev (Ekaterinburg 1921), 15; Pavel Bykov, Poslednie dni Romanovykh (Alma-Ata 1926 [1991]), 5; A. D. Avdeev, "Nikolai Romanov v Tobol'ske i Ekaterinburge," Krasnaia nov' No. 5 (1928), 198, 201; Vorob'ev, "Konets Romanovykh," 24; "Poslednii pereezd polkovnika Romanova. Iz vospominanii N. Nemtsova," Krasnaia niva No. 27 (1 July 1928).

${ }^{13}$.Trotsky developed the parallels between the two royal couples in The History of the Russian Revolution, 91-100. On Marie Antoinette see, Lynn Hunt, The Family Romance of the French Revolution (Berkeley 1992), 89-123. On the role of sexual imagery in revolutions see, Jeffrey Wasserstrom, "Gender and Revolution in Europe and Asia, Part 2: Recent Works and Frameworks for Comparative Analysis," Journal of Women's History 6 (Spring 1994): 115-117. ${ }^{14}$.Joseph T. Fuhrmann, Rasputin: A Life (New York 1990), 191-192, 214; Ross, $55,316,320,349$; V. S. Pankratov, $S$ tsarem v Tobol'ske: iz vospominanii (Moscow 1925 [1990], 22. Those sympathetic to the tsar and tsarina invariably felt the need to point out that the tsar drank little and that gossip about Alexandra and Rasputin was absolutely false, Nikolai Ross, Gibel' tsarskoi sem 'i: Materialy sledstviia po delu ob ubiistve tsarskoi sem'i (avgust 1918-fevral' 1920) (Frankfurt 1987), 308, 310, 425, 454.

${ }^{15}$ Michael Walzer, Regicide and Revolution: Speeches at the Trial of Louis XVI (Cambridge, UK 1974), 33.

16. "Manifest Rossiiskoi Sotsial-Demokraticheskoi Rabochei Partii," Izvestiia, 28 Feb. 1917; "Staryi poriadok pal," Pravda, 8 March 1917; M. Ol'minskii, "Respublika ili monarkhiia," Pravda, 8 March 1917; "Rabochii klass i respublika," Pravda, 11 March 1917. "Respublika," Izvestiia, 15 March 1917. Nemo, "Gde opasnost'?" Pravda, 27 April 1917; "Ob usloviiakh pobedy russkoi revoliutsii," Pravda, 18 March 1917.

${ }^{17}$.Most of the charges brought against Nicholas in the press after his execution can be found in the anti-tsarist tirades of early 1917. Lenin, "Pervyi etap pervoi revoliutsii," Pravda, 21 March 1917; "Volshebnaia skazka," Pravda, 12 March 1917; "Kak soderzhitsia Nikolai Romanov," Izvestiia, 15 March 1917; "Trebovanie naroda o zakliuchenii Nikolaia Romanova v krepost'," Krasnyi 
archiv 81(1937): 121-127.

18. "Respublika ili monarkhiia," Pravda, 8 March 1917; "Rabochii klass i respublika," Pravda, 11 March 1917; "Gde opasnost'?" Pravda, 27 April 1917. ${ }^{19}$.Trotsky, Trotsky's Diary in Exile, 1935, trans. Elena Zaudnaya (Cambridge, Ma. 1958), 81.

20. "Nakanune Moskovskogo Soveshchaniia," Izvestiia, 11 Aug. 1917; "Polgoda Revoliutsii," Izvestiia, 27 Aug. 1917; "Zagovor protiv Respubliki," Izvestiia, 23 Aug. 1917; “'Kontr-revoliutsionnyi zagovor," Izvestiia, 25 Aug. 1917.

21 ."Ne vse to zoloto..." Izvestiia, 20 July 1917; "Programma vlasti," Izvestiia, 8 July 1917.

22 ."Rech' Lenina," Izvestiia, 6 June 1917. See also Lenin, "O vragakh naroda," Pravda, 7 June 1917; "Mozhno-li zapugat' rabochii klass 'iakobinstvom'?" Pravda, 24 June 1917; Lenin, "Perekhod kontr-revoliutsii v nastuplenie ('Iakobintsy bez naroda')," Pravda, 28 May 1917.

23. "Rech' A. F. Kerenskogo," Izvestiia, 7 June 1917. See also "Rech' Martova," ibid.; "Rech' Bramsona," ibid. A similar debate occurred at the All-Russian Democratic Conference in September 1917. See "Rech' Trotskogo" and "Rech' Tseretelli," Izvestiia, 20 Sept. 1917.

${ }^{24}$.Alexander Kerensky, The Catastrophe: Kerensky's Own Story of the Russian Revolution (New York 1927), 259. See also Bykov, Poslednie dni, 22.

25 ."Prizyvy k mesti," Izvestiia, 28 May 1917. Kerensky, The Catastrophe, 261.

26 ."Perevod Nikolaia Romanova," Izvestiia, 6 Aug. 1917.

27. When Fannie Kaplan shot Lenin in August 1918, the press promptly dubbed the would-be assassin the "new Charlotte Corday," "Kto raduetsia s ubiitsami," Izvestiia, 1 Sept. 1918 ; "Novaia Sharlotta Korde," Pravda, 3 Sept. 1918.

${ }^{28}$.Keep, "1917," 32-33. Napoleon III illustrated the danger of a presidency in a republic, "Zadachi Uchreditel'nogo Sobraniia," Izvestiia, 13 April 1917. On the Bolsheviks as Napoleons, see "Rech' Tseretelli," Izvestiia, 20 Sept. 1917 and "Rabochie i soldaty!" Izvestiia, 24 Oct. 1917; Lenin, "Ishchut Napoleona," Pravda, 10 May 1917; Lenin, "Nachalo bonapartizma," Rabochii i soldat, 29 July 1917; "To, chto est'," Rabochii put', 7 Sept. 1917; Trotsky, "Vserossiiskoe Demokraticheskoe Soveshchanie. Rech'Trotskogo," Izvestiia, 20 Sept. 1917; V. Bystrianskii, "O Bonapartizme," Pravda, 16 Nov. 1917.

${ }^{29}$.Brovkin, Behind the Lines, 62, 88, 291.

30. "Frantsiia v 1793 godu," Izvestiia, 8 Aug. 1918; "Russkaia Vandeia," Izvestila, 24 Nov. 1917; “Dve revoliutsii," Pravda, 22 Dec. 1917.

31 “"Sovety i kontr-revoliutsiia (1871 g. -1917 g.)," Pravda, 2 Nov. 1917.

32 ."Dve revoliutsii," Pravda, 22 Dec. 1917.

33.Brovkin, Behind the Lines, 19; "S Novym godom," Pravda, 31 Dec. 1917; "Otechestvo v opasnosti," Izvestiia, 22 Feb. 1918; "Soiuzniki i Nikolai," Izvestiia, 20 March 1918; "Frantsiia v 1793 godu," Izvestiia, 8 Aug. 1918; "Bor'ba s kontr-revoliutsiei v 1789-1793 g. g.," Pravda, 18 Sept. 1918.

34. "Samoderzhavie naroda," Pravda, 1 Dec. 1917; "Ekstsessy vo vremia 
revoliutsii," Pravda, 23 Jan 1918, evening ed.

35. "Terror i grazhdanskaia voina," Izvestiia, 5 Nov. 1917; Heinrich Heine, "A Winter's Tale" in The Complete Poems of Heinrich Heine, ed. Hal Draper (Boston 1982), 532.

${ }^{36}$.Lynn Hunt calls the execution of Louis XVI "the most important political act of the Revolution," The Family Romance of the French Revolution, 2.

37. Trotsky, Trotsky's Diary in Exile, 80. Trotsky himself was to take the role of lead prosecutor. P. M. Bykov, Poslednie dni, 89; Ross, Gibel'tsarskoi sem 'i, 20. 38. "Liudovik XVII," Pravda, 19 Dec. 1917. Throughout the Civil War, political cartoons appeared irregularly and infrequently in Pravda. This circumstance may have magnified the importance of those that did appear, especially from the editors' point of view, and perhaps for the paper's reading public (largely party activists) as well.

${ }^{39}$.Through early 1918, Lenin seemed unable to characterize Nicholas as anything other than an idiot. See for example, Lenin, Collected Works (hereafter: $C W$ ), (Moscow 1977), 27:64, 166, 225, 307. On the tardiness of the regicide see ibid., 27: 498; "O vragakh naroda," Pravda, 7 June 1917. On tsarism as the "symbol of semi-feudal Russia," see "Kontr-revoliutsiia i bonapartizm," Izvestiia, 18 June 1918

${ }^{40}$.Lenin, $C W, 28:$ 80; "Krakh zagovorshchichestva," Pravda, 16 July 1918.

41 . The Bolshevik press and, apparently, revolutionaries of all stripes were scrupulous about referring to Nicholas II as "byvshii tsar." Ross, Gibel 'tsarskoi sem 'i, 295; Trotsky, "Velikoe vremia," Pravda, 6 March 1919. See also "God ..." Pravda, 12 March 1918; "Iubilei," Pravda, 12 March 1918; "Dva fevralia," Pravda, 13 March 1918, evening ed; "Krasnyi god," Izvestiia, 14 March 1918.

${ }^{42}$.Marc Ferro, Nicholas II: The Last of the Tsars, trans. Brian Pearce (London 1991), 285.

43. "Tainaia vecheria," Pravda, 8 Nov. 1917.

44 . "V Tsarskom Sele," Izvestiia, 28 May 1917; "K perevodu byvshego tsaria iz Tobol'ska v Ekaterinburg," Izvestiia, 16 May 1918.

${ }^{45}$.Lenin, "Speech at a Meeting in the Basmanny District, 30 Aug. 1918," CW, 28: 88; "Kontr-revoliutsiia i bonapartizm," Izvestiia, 18 June 1918; "Byvshie generaly, pomeshchiki, bankiry - podnimaiut golovy," Izvestiia, 31 May 1918; "Vseobshchaia stachka protiv rabochego klassa," Izvestiia, 4 June 1918; "Mikhail Romanov i Aleksandr Kerensky," Pravda, 2 July 1918; "Vnimanie proletari!" Pravda, 3 Sept. 1918.

${ }^{46}$.In addition to articles cited in n. 45, see for example "Doklad Sledstv. Komissii po delu o zagovore monarkhicheskoi organizatsii V. Purishkevicha," Pravda, 21 Dec. 1917; "Nemetskii imperator i russkii tsar," Pravda, 10 Feb. 1918; "Germanskii imperializm vozdvigaet korolevskie trony," Pravda, 9 May 1918; "Molchalivoe soglashenie," Izvestiia, 4 June 1918; "Khochetsia na prestol," Izvestiia, 25 June 1918; "Reaktsionnyi blok," Izvestiia, 13 July 1918; "Chernyi zagovor," Izvestiia, 4 Aug. 1918; "Soiuznicheskii imperializm i 
russkaia monarkhiia," Izvestiia, 6 Aug. 1918; "Soiuzniki i restavratsiia," Izvestiia, 8 Aug. 1918; "Nashi vragi," Izvestiia, 10 Aug. 1918; Ross, Gibel' tsarskoi sem'i, 18.

47 François Furet, Interpreting the French Revolution, trans. Elborg Forster (Cambridge, UK 1981), 55. Walzer explains the obsession with conspiracy as a reaction against the court, which is "a world of conspiracy, of private intrigues with public effects." See Regicide and Revolution, 28.

${ }^{48}$.See headlines between late summer and early fall 1918. "Nakanune," Izvestiia, 21 July 1918. On the centrality of the "aristocratic plot" in the symbolic universe of the French Revolution, see Hunt, Family Romance.

49. "Klass i partiia," Izvestiia, 12 Sept. 1918; Lenin, "Letter to American Workers (20 Aug. 1918)," CW, 28: 71.

50 . "Kto kontr-revoliutsioner?" Izvestiia, 30. Nov. 1917; "Dva lageria," Izvestiia, 13 Jan. 1918; Iu[rii] Steklov, "Zatei kontr-revoliutsii," Izvestiia, 22 Aug. 1918; "Kto raduetsia s ubiitsami," Izvestiia, 1 Sept. 1918.

51 ."Kto kontr-revoliutsioner?" Izvestiia, 30 Nov. 1917.

52. "Kadetskii monarkhicheskii zagovor raskryt," Pravda, 1 Dec. 1917; "K.-D. Pod maskoi. Maska sorvana," Pravda, 13 Dec. 1917; V. Bystrianskii, "Marks i nashi 'marksisty' ob Uchreditel'nom Sobranii," Pravda, 20 Dec. 1917; "Kontrrevoliutsiia pod flagom marksizma," Izvestiia, 7 June 1918.

53. "Dnevnik N. Romanova," Pravda, 18 Aug. 1918; Avdeev, "Nikolai Romanov," 200; Bykov, Poslednie dni, 54, 83.

54 Trotsky, Trotsky's Diary in Exile, 80.

${ }^{55}$ Pipes, The Russian Revolution, (New York 1990), 750-758.

${ }^{56}$. The first detailed Soviet account of the murders, which largely squared with that produced by White investigators, was Bykov, "Poslednie dni poslednego tsaria" in Rabochaia revoliutsiia na Urale: Epizody i fakty, ed. N. I. Nikolaev (Ekaterinburg 1921), 3-26. As late as 1922, Georgii Chicherin (at the Genoa Conference) denied that the entire family had been killed, "Unrepentant Bolshevism," The Times of London, 25 April 1922, 13.

${ }^{57}$.This is by no means an exhaustive catalog of the various solutions to the puzzle of what happened to the Romanovs and why. The sources here are vast. The basic account is that of the White investigator Nicholas Sokolov, Ubiistvo tsarskoi sem 'i (Berlin 1925). Much of the material collected by the Sokolov investigation is available in Ross, Gibel'tsarskoi sem 'I; Mark Steinberg and Vladimir Khrustalëv, The Fall of the Romanovs: Political Dreams and Personal Struggles in a Time of Revolution (New Haven 1995) does an excellent job of connecting the regicide to the popular revolution, and provides both a balanced analysis of competing theories and useful documents. Ferro examines the evidence for the escape of at least some members of the family, Nicholas II, 233287. Pipes makes the case for viewing the regicide as a crime orchestrated in Moscow, and then blamed on the Ural Regional Soviet, The Russian Revolution, 745-788. A recent Russian account that presents numerous speculations about 
Romanovs who may have gotten away is Edvard Radzinsky, The Last Tsar: The Life and Death of Nicholas II, trans. Marian Schwartz (New York 1992). For a sense of the popular fascination with the regicide and a review of recent DNA testing that aims to solve the mystery once and for all, see Robert K. Massie, "The Last Romanov Mystery," The New Yorker (21 and 28 Aug. 1995), 72-95. ${ }^{58}$ Trotsky, Trotsky's Diary in Exile, 82.

${ }^{59}$ Ibid., 81.

60. "Nikolai Romanov," Pravda, 19 July 1918; a translation of this editorial may be found in Steinberg and Khrustalëv, The Fall of the Romanovs, 341-343; Iu[rii] Steklov, "Konets posledysha," Izvestiia, 20 July 1918; "Poslednii mogikan," Izvestiia, 20 July 1918; Bela Kun, "Pitomnik monarkhii," Pravda, 20 July 1918; N. B., "Tsaria," Pravda, 20 July 1918; S. T - iu, "Nikolai poslednii i Pol'sha," Izvestiia, 21 July 1918; N. Antonov, "Karl I - Liudovik XVI-i - Nikolai II-i," Pravda, 21 July 1918; "Provintsial'nye gazety o rasstrele Nikolaia Romanova," Izvestiia, 24 July 1918.

${ }^{61}$.I have found only one reference to the execution of Marie-Antoinette: "Bor'ba s kontr-revoliutsiei v 1789-1793 g. g.," Pravda, 18 Sept. 1918. Shlapentokh notes that liberals compared Alexandra to Marie-Antoinette, The French Revolution and the Russian Anti-Democratic Tradition, 231.

62. "Karl I," 2. See Hunt, The Family Romance of the French Revolution, 55; Walzer, Regicide and Revolution, 58-66.

63. "'Za veru, tsaria i otechestvo' (beseda s tov. Petersom)," Izvestiia, 28 July 1918; "V stane kontr-revoliutsii. 'Orden Romanovtsev,"” Izvestiia, 2 March 1919.

${ }^{64}$.M. N. Pokrovskii, Istoriia osvobozhdeniia Rossii (Moscow, 1918) quoted in G. Z. Ioffe, Krakh Rossiiskoi monarkhicheskoi kontrrevoliutsii, 4. British journalist Francis McCullagh reported that this view was widely held in Siberia (once again Red) in 1920. A Prisoner of the Reds: The Story of a British Officer Captured in Siberia (London 1921), 119.

${ }^{65}$.Pravda, $12 \mathrm{March} / 27$ Feb. o.s. 1918.

${ }^{66}$ In his account of the "murder of the imperial family," Pipes emphasizes that "Nicholas II was neither charged nor tried. ... The deed, perpetrated in the dead of night, resembled more a gangster-type massacre than a formal execution." The Russian Revolution, 746. Walzer concludes that where revolutionaries fail to stage the regicide as a public ritual, "it is far more likely than it ever was in England and France that the mysteries of government will outlast the 'last' king and will be re-embodied in men who make up in brutality what they lack in divine right." Regicide and Revolution, 88-89.

${ }^{67}$.Bykov, "Poslednie dni," 17-20; Bykov, Poslednie dni, 89-94, 98; Avdeev, "Nikolai Romanov," 197, 207, 209.

${ }^{68}$.Trotsky, Trotsky's Diary in Exile, 81, 82.

${ }^{69}$.Vorob'ev, "Konets Romanovykh," 26; Bykov, "Poslednie dni," 22.

${ }^{70}$.See $n .14$ above. The SR in charge of the tsar's imprisonment under the 
Provisional Government describes Nicholas and Alexandra in the same way, Pankratov, $S$ tsarem, 14, 29, 48.

${ }^{71}$.Avdeev, "Nikolai Romanov," 200, 203.

72 .Bykov, "Poslednie dni," 21, 22; In Vorob'ev, "Konets Romanovykh," 26.

73."Iz vospominanii komendanta doma osobogo naznacheniia $\mathrm{v} g$. Ekaterinburge Ia. M. Iurovskogo" in P. M. Bykov, Poslednie dni Romanovykh (Sverdlovsk 1990), 106-107.

${ }^{74}$.One awkward, if not absurd, consequence of the Bolshevik tendency to think in terms of "two camps" was that the SR's were at once implicated in monarchist plots and charged with pressuring the Bolsheviks to kill the tsar without trial. Bykov, "Poslednie dni," 17, 19; Poslednie dni, 89, 97. Ross, Gibel' tsarskoi sem' $i, 18$.

${ }^{75}$.Bykov, Poslednie dni, 82; Avdeev, "Nikolai Romanov," 187.

${ }^{76}$.Kerensky, The Catastrophe, 272; Bykov, "Poslednie dni," 3, 7-13, 21; Bykov, Poslednie dni, 70-73, 74-84; Avdeev, "Nikolai Romanov," 196-197; Avdeev, "Iz istoriii bor'by za sovety: Oktiabr'skie dni i organizatsiia otriada krasnoi gvardii," Proletarskaia revoliutsiia No. 9 (1930): 105-107; "Poslednii pereezd polkovnika Romanova: iz vospominanii N. Nemtsova," Krasnaia niva No. 27 (1 July 1928).

77. Vorob'ev, "Konets Romanovykh," 26.

${ }^{78}$.Bykov, Poslednie dni, 94; Avdeev, "Nikolai Romanov," 205-206.

${ }^{79}$.Bykov, "Poslednie dni," 3, 25, 26.

${ }^{80}$.Bykov, Poslednie dni, 109, 110.

${ }^{81}$.Trotsky, The Revolution Betrayed: What Is the Soviet Union and Where Is It Going? trans., Max Eastman (New York 1937 [1977]), 89.

${ }^{82}$.Hunt notes a "tension between forgetting and commemorating" the regicide in France, The Family Romance of the French Revolution, 62.

${ }^{83}$.Bykov, Poslednie dni, 100-101; Vorob'ev, "Konets Romanovykh," 26.

${ }^{84}$.Bykov, "Poslednie dni,"22, 3; see also his Poslednie dni, 90. For Avdeev, the regicide was important primarily because it allowed the three-hundred men guarding the imperial family to join the struggle against the Whites, 209. Trotsky represented himself as too busy to take much initiative to discover what happened to the tsar, but he considered the regicide a "great political turning point," Trotsky's Diary in Exile, 81.

${ }^{85}$.Bykov, Poslednie dni, 107, 83. The 1926 edition does not mention the renaming of Ascension Square Ploshchad' Narodnoi Mesti, 85. McCullagh noted the new name (he calls it the "Square of National Vengeance") in 1920, $A$ Prisoner of the Reds, 115.

86.Vorob'ev, "Konets Romanovykh," 26. Ioffe, Krakh Rossiiskoi monarkhicheskoi kontrrevoliutsii, 129; Ferro, Nicholas II, 284-285.

${ }^{87}$.A. Iu. Polunov, "Romanovy: Mezhdu istoriei i ideologiei" in Istoricheskie issledovaniia $\vee$ Rossii: tendentsii poslednikh let, ed. G. A. Bordiugov (Moscow 1996), 84-86. 